\title{
ANALISIS EFISIENSI PASAR MODAL KONVENSIONAL BENTUK LEMAH DI BURSA EFEK INDONESIA PERIODE 2014-2015
}

\author{
Ade Lisa Istifarida \\ adelisaistifarida@yahoo.co.id \\ Universitas Ahmad Dahlan \\ Salamatun Asakdiyah \\ salamatun_2009@yahoo.com \\ Universitas Ahmad Dahlan
}

\begin{abstract}
ABSTRAK
The purpose of this study is to determine efficiency in a weak form conventional capital market in Indonesia using stock price data weekly in the 2014-2015 period. Techniques in testing market efficiency forms. This weakness uses a purposive sampling technique as well as a method for data collection using the documentation method. Obtained 36 companies which is included in the LQ-45 index which is used as a research sample. Testing the hypothesis of a weak form of capital market efficiency using the run test test. The results of this study, that the conventional capital market is efficient in a weak form using stock price information for the period research. It is proven by 33 shares $(91.7 \%)$ moving randomly (random) and 3 shares (8.3\%) move non-randomly (not randomly). Then it can be concluded that the conventional capital market is efficient in its form weak.
\end{abstract}

Keywords: LQ-45; Conventional Capital Market; Weak Form; Run Test.

PENDAHULUAN

Pasar modal (capital market) merupakan tempat perdagangan instrumen keuangan (sekuritas) jangka panjang, baik dalam bentuk modal sendiri (stock) atau hutang (bond) yang diterbitkan oleh pemerintah maupun oleh perusahaan swasta. Pasar modal merupakan sarana untuk mempertemukan penawar dan permintaan dalam bentuk efek, sehingga pasar modal sering disebut sebagai bursa efek. Sesungguhnya ada perbedaan mendasar antara pasa modal (stock market) dengan bursa efek (stock exchange). Pasar modal merupakan tempat perdagangan surat berharga (stock dan bond), sedangkan Bursa efek merupakan pihak yang menyelenggarakan dan menyediakan sistem dan/atau sarana untuk memepertemukan penawaran jual dan beli efek di antara mereka (Yusgiantoro, 2004).
Menurut Tandelilin (2010) Pasar modal merupakan pertemuan antara pihak yang memiliki kelebihan dana dengan pihak yang membutuhkan dana dengan cara memperjualbelikan sekuritas. Pasar modal juga dapat diartikan sebagai pasar untuk memperjualbeikan sekuritas yang memiliki umur lebih dari satu tahun, seperti saham dan obligasi. Sedangkan tempat terjadinya jual beli sekuritas disebut sebagai bursa efek. Oleh karena itu bursa efek sendiri dapat diartikan sebagai bentuk fisik dari pasar modal.

Dalam kegiatan investasi di pasar modal tentu saja investor memiliki tujuan untuk memperoleh keuntungan dari apa yang telah mereka tanamkan. Investasi di awali dengan mengorbankan dananya dimasa kini untuk memperoleh keuntungan di masa datang. Investasi merupakan salah satu ajaran dari konsep Islam yang memenuhi proses tadrij dan trichotomy pengetahuan tersebut. Hal 
tersebut dapat dibuktikan bahwa konsep investasi selain sebagai pengetahuan juga bernuansa spiritual karena menggunakan norma syariah, sekaligus merupakan hakikat dari sebuah ilmu dan amal, oleh karenanya investasi sangat dianjurkan bagi setiap muslim (Huda, 2007).

Informasi merupakan salah satu faktor penting bagi investor untuk mencapai tujuan di pasar modal, yaitu memperoleh profit. Berdasarkan informasi yang ada faktor kunci bagi investor di Pasar Modal dalam rangka mewujudkan tujuannya yaitu memperoleh profit. Berdasarkan informasi yang tersedia, investor akan mengambil keputusan kapan akan membeli saham atau mempertahankan saham yang telah dimiliki atau kapan akan melepas saham atau tidak melakukan pembelian sama sekali. Terdapat banyak sekali investor di pasar modal, mereka juga akan mengambil keputusan berdasarkan informasi yang diterima masingmasing sehingga pada waktu yang hampir bersamaan mereka akan melakukan beli atau jual (Khajar, 2008).

Informasi diperoleh dalam bentuk acak dan bebas yang setiap saat dapat muncul. Artinya, hampir semua investor tidak dapat memprediksi kapan perusahaan akan mengumumkan perkembangan baru yang penting (Gunanti, 2002). Sebagai contohnya kapan bencana alam akan terjadi, kapan nilai tukar rupiah akan terpuruk atau kapan pemilik perusahaan terkena serangan jantung secara mendadak.

Salah satu faktor yang mendukung kepercayaan investor adalah persepsi mereka akan kewajaran harga sekuritas (saham). Dalam keadaan seperti itu pasar modal dikatakan efisiensi secara informasional. Pasar modal dikatakan efisien secara informasional apabila harga sekuritasnya mencerminkan semua informasi yang relevan. Semakin tepat dan cepat informasi sampai ke calon investor dan dicerminkan pada harga saham, maka pasar modal yang bersangkutan semakin efisien. Informasi yang sepenuhnya tercermin pada harga saham akan sangat berharga bagi para pelaku pasar modal dan institusi yang berkaitan (Mar'ati, 2012).

Pasar modal yang efisien adalah pasar di mana harga semua sekuritas yang diperdagangkan telah mencerminkan semua informasi yang tersedia. Konsep pasar yang efisien menyiratkan adanya suatu proses penyesuaian harga sekuritas menuju harga keseimbangan yang baru, sebagai respon atas infomasi baru yang masuk ke pasar (Tandelilin, 2010).

Menurut Hartono (2014) Efisien pasar modal dapat dibedakan menajadi tiga bagian yaitu: pertama, efisiensi pasar modal dalam bentuk lemah dimana harga sekuritas saat ini mencerminkan semua informasi masa lalu (historis). Kedua, efisien pasar bentuk setengah kuat, yaitu harga sekuritas saat ini mencerminkan semua informasi masa lalu (historis) dan informasi yang di publikasikan saat ini. Ketiga, pasar efisien bentuk kuat yaitu harga sekuritas saat ini mencerminkan semua informasi masa lalu (historis), informasi yang dipublikasi saat ini dan informasi yang tidak terpublikasi.

Penelitian yang dilakukan oleh Astuti (2009) dengan menggunakan sampel 11 indek yang ada yaitu IHSG, LQ 45 dan sembilan sektor industri dengan uji statistik Run Test dan Kolmogorov Semirnov dapat disimpulkan bahwa hampir seluruh indeks saham yang diperdagangkan sudah efisien dalam bentuk lemah, kecuali indeks saham infrastruktur yang belum efisien dalam bentuk lemah.

Penelitian Khajar (2008) menggunakan 6 sampel saham yang tergabung dalam indeks JII dengan uji statistik Run Test dapat disimpulkan bahwa Pasar modal syariah Indonesia sudah efisien paling tidak dalam bentuk lemeh, namun pada saat krisis keuangan global 2008 efisiensi mengalami 
penurunan dan kembali meningkat setelahnya. Tujuan dari penelitian ini untuk mengetahui efisiensi dalam bentuk lamah pasar modal konvensional di Indonesia pada priode 2014-2015.

\section{REVIEW LITERATUR DAN HIPOTESIS}

\section{Landasan Teori}

1. Pasar Modal

Menurut Darmadji (2008) pasar modal (capital market) merupakan pasar untuk berbagai instrumen keuangan jangka panjang yang bisa diperjualbelikan, baik dalam bentuk utang, ekuitas (saham), isntrumen derivatif, maupun instrumen lainnya.

\section{Indeks Harga Saham}

Menurut Samsul (2006) Indeks harga saham adalah harga saham yang dinyatakan dalam angka indeks. Indeks saham digunakan untuk tujuan analisis dan menghindari dampak negatif dari penggunaan harga saham dalam rupiah.

\section{Pasar Efisien}

Hartono (2014) mengemukakan bahwa pasar yang efisein ketika informasi yang tersedia di pasar dapat diterima dengan cepat dan akurat untuk mencapai harga keseimbangan yang baru.

\section{Penelitian Terdahulu}

Khajar (2012) dengan judul “Analisis Efisiensi Pasar Modal Syariah Dan Konvensional Bentuk Lemah Bursa Efek Indonesia Periode 2010" berdasarkan hasil uji statistik run test, dapat disimpulkan bahwa pasar modal syariah dan konvesional pada periode 2010 sudah efisien paling tidak dalam bentuk lemah. Namun, pasar modal syariah lebih efisien dibandingkan pasar modal konvensional, karena berdasarkan hargaharga saham (sampel penelitian) $100 \%$ saham syariah bersifat random (efisien bentuk lemah) sedangkan konvensional hanya $65 \%$.

Penelitian yang dilakukan oleh Dewi (2008) dengan judul "Pengujian Efisiensi Pasar Modal Melalui Evaluasi Pergerakan Indeks LQ-45 di Bursa Efek Indonesia (BEI)" menggunakan data return indeks LQ-45 dengan menggunakan metode ARCH dan GARCH dapat disimpulkan bahwa pasar modal Indonesia dapat dikatakan belum efisien dalam bentuk lemah.

\section{Hipotesis}

H1: Pasar modal konvensional periode 2014-2015 sudah efisien dalam bentuk lemah.

\begin{tabular}{l}
\hline METODE PENELITIAN \\
Populasi dan Sampel \\
Populasi adalah wilayah generalisasi \\
yang terdiri atas obyek atau subyek yang \\
mempunyai kualitas dan karakteristik \\
tertentu yang ditetapkan oleh peneliti \\
untuk dipelajari dan kemudian ditarik \\
kesimpulannya. Sampel adalah bagian \\
dari jumlah dan karakteristik yang \\
dimiliki oleh populasi tersebut (Sugiyono, \\
2010). Menurut Suharyadi (2004) populasi \\
adalah kumpulan dari semua kemungkinan \\
orang-orang, benda-benda dan ukuran lain \\
yang menjadi objek perhatian atau \\
kumpulan seluruh objek yang menjadi \\
perhatian. Adapun populasi dalam \\
penelitian ini adalah seluruh saham \\
konvensional (LQ45) periode 2014-2015. \\
Menurut Suharyadi (2004) sampel \\
merupakan bagian dari populasi. Dengan \\
menggunakan sampel, maka dapat \\
diperoleh suatu ukuran yang dinamakan \\
statistik. Ada banyak cara yang dapat \\
digunakan untuk pengambilan sampel. \\
Teknik pengambilan sampel dalam \\
penelitian ini dipilih \\
menggunakan metode nonprobability \\
sampling, dengan teknik purposive \\
sampling yaitu pengambilan sampel \\
dengan kriteria tertentu. Sebagai dasar
\end{tabular}


pertimbangan pemilihan sampel, adapun kriteria pengambilan sampel adalah sebagai berikut:

1. Saham tersebut menjadi anggota tetap selama dua periode berturutturut yaitu periode Februari - Juli 2014, Agustus 2014 - Januari 2015, Februari - Juli 2015 dan Agustus 2014 Januari 2016 (Indeks LQ-45).

2. Data harga saham yang digunakan adalah harga saham mingguan pada periode 2014-2015.

Dengan kriteria di atas, maka terdapat 36 perusahaan yang menjadi sampel penelitian adalah sebagai berikut:

Sampel Uji Efisiensi Bentuk Lemah

\begin{tabular}{|c|c|}
\hline Keterangan & Jumlah \\
\hline 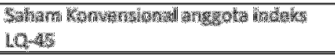 & 45 \\
\hline 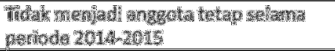 & (9) \\
\hline Total sampel & 36 \\
\hline
\end{tabular}

\section{Definisi Operasional}

Variabel utama dalam penelitian ini adalah return indeks saham LQ-45, yaitu selisih antara harga minggu ini dengan harga minggu kemarin.

$$
\text { Rit }=\frac{P t-P t_{-1}}{P t_{-1}}
$$

Dimana:

Rit = Return saham sesungguhnya pada saham i periode $t$

$\mathrm{Pt}=$ Harga pembukaan saham i pada periode $\mathrm{t}$

$\mathrm{Pt}_{-1}=$ Harga penutupan saham i pada saat $\mathrm{t}-1$

\section{Teknik Analisis Data}

\section{Return Saham}

Variabel utama dalam penelitian ini adalah return indeks LQ-45, yaitu selisih antara minggu ini dengan minggu kemarin.

$$
\text { Rit }=\frac{P t-P t_{-1}}{P t_{-1}}
$$

Dimana:

Rit = Return saham sesungguhnya pada saham i periode $\mathrm{t}$

$\mathrm{Pt}=$ Harga pembukaan saham i pada periode $\mathrm{t}$

$\mathrm{Pt}_{-1}=$ Harga penutupan saham i pada saat t-1

\section{Run Test}

Uji run (run test) akan digunakan untuk melihat random tidaknya hargaharga saham yang dijadikan sampel penelitian. Teknik ini memungkinkan peneliti menguji hipotesis apakah harga -harga saham untuk suatu periode tertentu bersifat random atau non random (Khajar, 2012).

Pada analisis run, perubahan harga ditandai dengan (+) bila terjadi kenaikan harga, (-) bila terjadi penurunan harga dan (0) bila tidak terjadi perubahan. Kemudian jika perubahan harga berhubungan positif, maka kecenderungannya a + akan diikuti oleh a+ dan a- juga akan diikuti oleh a-. Urutan tanda yang sama diantara tanda yang berbeda disebut dengan run (Tandelilin, 2010).

Dalam run test menggunakan uji $\mathrm{Z}$, dengan langkah yang digunakan oleh (Herman, 1998 dalam Nasruldin, 2011):

a. Bandingkan perubahan saham mingguan dengan harga saham mingguan sebelumnya.

b. Temukan posisi perubahannya (naik, turun, tetap).

c. Hitung jumlah masing-masing tanda setiap saham.

d. Hitung runtun sesungguhnya (R) periode yang diobservasi.

e. Hitung expected run, untuk seluruh tanda dengan rumus:

$$
M=\frac{\left[N(N+1)-\sum_{i=1}^{3} n_{i}^{2}\right.}{N}
$$

Keterangan:

$\mathrm{M}=$ Total jumlah run yang diharapkan

$\mathrm{N}=$ total jumlah perubahan harga 
$\mathrm{Ni}=$ jumlah perubahan harga untuk setiap tanda

f. Hitung deviasi standar dengan rumus:

$\sigma M=\sqrt{\frac{\left\{\sum_{t=1}^{3} n_{1}^{2}\left[\sum_{t=1}^{3} n_{1}^{2}+N(N+1)-2 N \sum_{t=1}^{3} n_{1}^{2}-N^{3}\right.\right.}{N^{2}(N-1)}}$

g. Menghitung Z, karna perubahan harga mengikuti atau menyesuaiakan dengan distribusi normal (random walk) dengan rumus:

$$
Z_{\text {hit }}=\frac{[(R \pm 1 / 2)-m]}{\sigma_{M}}
$$

Dimana: $R$ adalah jumlah runtun sesungguhnya $\pm 1 / 2$ adalah koreksi kontinum $( \pm 1 / 2$ jika $R<m$ dan $- \pm 1 / 2>m)$

h. Menentukan a dan mengevaluasi pengelolaan data berdasarkan nilai $\mathrm{Z}$ yang didapat.

i. Menentukan randomness test, jika besar asymp.sig lebih besar dari a, maka sample probabilitas tinggi.

\section{Uji Hipotesis}

1. Rumusan hipotesis:

H1: Pasar modal konvensional periode 2014-2015 sudah efisien dalam bentuk lemah.

2. Kriteia penerimaan dan penolakan:

a. Hasil pengujian ini dikatakan signifikan (Ha diterima) apabila nilai asymp sign. dua sisi lebih kecil dari a (5\%), artinya hargaharga saham konvensional tidak bersifat random sehingga dikatakan tidak efisien dalam bentuk lemah.

b. Hasil pengujian ini dikatakan signifikan (Ho diterima) apabila nilai asymp sign. dua sisi lebih besar dari a (5\%), artinya hargaharga saham konvensional bersifat random sehingga dikatakan efisien dalam bentuk lemah.

\section{HASIL PENELITIAN DAN PEMBAHASAN}

\section{Hasil Penelitian}

1. Hasil Uji Run

Pengujian pasar modal bentuk lemah dilakukan dengan uji run test, untuk mengetahui kerandoman atau keacakan sebuah rangkaian kejadian, hal atau simbol merupakan hasil proses yang acak atau random.

Berdasarkan alat analisis uji run, maka rumusan hipotesis sebagai berikut:

Ho : Pasar modal konvensional sudah efisien dalam bentuk lemah.

Ha : Pasar modal konvensional belum efisien dalam bentuk lemah.

Dengan kriteria penerimaan dan penolakan sebagi berikut:

a. Hasil pengujian ini dikatakan signifikan (Ha diterima) apabila nilai asymp sign. dua sisi lebih kecil dari a (5\%), artinya harga-harga saham konvensional tidak bersifat random sehingga dikatakan tidak efisien dalam bentuk lemah.

b. Hasil pengujian ini dikatakan signifikan (Ho diterima) apabila nilai asymp sign. dua sisi lebih besar dari a (5\%), artinya harga-harga saham konvensional bersifat random sehingga dikatakan efisien dalam bentuk lemah.

Pengujian run test dilakukan dengan bantuan komputer program Microsoft Excel 2007 dan SPSS statistics version 20. Dihitung return sahamnya masing-masing untuk memperoleh nilai Z-hitung dan asymp sig. masing-masing perusahan sampel. 
Hasil Run Test Saham Konvensional

\begin{tabular}{|c|c|c|c|c|c|}
\hline NO & $\begin{array}{l}\text { KODE } \\
\text { EMITEN }\end{array}$ & NAMA PERUSAHAAN & $z$ & $\begin{array}{l}\text { ASYMP } \\
\text { SIG. }\end{array}$ & KETERANGAN \\
\hline 1 & AALI & Astra Agro Lestari Tbk. & 0,406 & 0,685 & Random \\
\hline 2 & ADHI & Adhi Karya (Persero) Tbk. & 1,020 & 0,308 & Random \\
\hline 3 & ANRO & Afdaro Fnergy Thk. & $-0,203$ & 0,839 & Randinm \\
\hline S & AkTh & ANR Conpotinde thy & Whas & 9,52 & 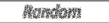 \\
\hline 5 & Msii & 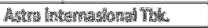 & 1,05 & 310 & Mundoren \\
\hline 6 & ASN & Alam Sutra Rusuly The & 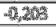 & aras & hoodbavan \\
\hline 7 & sina & 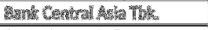 & 2031 & 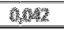 & Ther Howation \\
\hline 稟 & 68: & 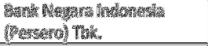 & $-6,539$ & 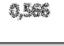 & Famelion \\
\hline 9 & 8 & 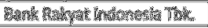 & 0, is & 419 & Alandon: \\
\hline 10 & sMisio & 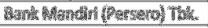 & 3,134 & 9,0002 & Tidak homings \\
\hline 11 & BMTN & Global Mexillown The & 102 & 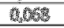 & Mosedasm \\
\hline 12 & BSDE & Bumi Serpong Damai Tbk. & 1,015 & 0,310 & Random \\
\hline 13 & CPIN & $\begin{array}{l}\text { Charoen Pokpand Indonesia } \\
\text { Tbk. }\end{array}$ & $-0,402$ & 0,688 & Random \\
\hline 14 & EXCL & XL Axiata Tbk. & $-1,218$ & 223 & Random \\
\hline 15 & GGRM & Gudang Garam Tbk. & 2,843 & 0,004 & Tidak Random \\
\hline 16 & ICBP & $\begin{array}{l}\text { Indofood CBP Sukses } \\
\text { Makmur Tbk. }\end{array}$ & $-0,402$ & 0,688 & Random \\
\hline 17 & INDF & $\begin{array}{l}\text { Indofood Sukses Makmur } \\
\text { Tbk. }\end{array}$ & 1,218 & 223 & Random \\
\hline 18 & INTP & $\begin{array}{l}\text { Indocement Tunggal } \\
\text { Perkasa Tbk. }\end{array}$ & 0,609 & 0,542 & Random \\
\hline 19 & ITMG & $\begin{array}{l}\text { Indo Tambang Raya Megah } \\
\text { Tbk. }\end{array}$ & $-0,812$ & 0,417 & Random \\
\hline 20 & JSMR & Jasa Marga (Persero) Tbk. & 1,244 & 213 & Random \\
\hline 21 & KLBF & Kalbe Farma Tbk. & 0,564 & 0,573 & andom \\
\hline 22 & LPKR & Lippo Karawaci Tbk. & $-1,218$ & 0,223 & Random \\
\hline 23 & LSIP & $\begin{array}{l}\text { PP London Sumatra } \\
\text { Indonesia Tbk. }\end{array}$ & 0,609 & 0,542 & Random \\
\hline 24 & MACN & 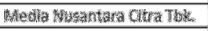 & 2,609 & 0542 & Sandom \\
\hline 28 & GSAS & $\begin{array}{l}\text { Perwahoman Gas Negara } \\
\text { Thk: }\end{array}$ & 0,609 & 0,54 & handwan \\
\hline 26 & PreA & $\begin{array}{l}\text { Tambang Eatubara Bukit } \\
\text { Asam Thks }\end{array}$ & $-0,406$ & 0,685 & Pandons \\
\hline 27 & PTe & Pe (Penserol Thlok & 0,812 & Q,417 & Flandom \\
\hline 28 & PWON & Takowond lat Tbk. & 1853 & 0,067 & Rand dom \\
\hline 29 & SMGS & $\begin{array}{l}\text { Sernes lintanessia (Persero) } \\
\text { Thk. }\end{array}$ & 1,625 & 0,104 & Rathdory \\
\hline
\end{tabular}

\begin{tabular}{|c|c|c|c|c|c|}
\hline 30 & SMRA & Summarecon Agung Tbk. & $-0,609$ & 0,542 & Random \\
\hline 31 & TBIG & \begin{tabular}{|l|} 
Tower Bersama \\
Infrastruktur Tbk.
\end{tabular} & 0,017 & 0,987 & Random \\
\hline 32 & TLKM & \begin{tabular}{|l|} 
Telekomunikasi Indonesia \\
(Persero) Tbk.
\end{tabular} & $-0,406$ & 0,685 & Random \\
\hline 33 & UNTR & \begin{tabular}{|l} 
United Tractors Tbk. \\
\end{tabular} & 1,015 & 0,310 & Random \\
\hline 34 & UNVR & Unilever Indonesia Tbk. & 1,828 & 0,068 & Random \\
\hline 35 & WIKA & \begin{tabular}{|l} 
Wijaya Karya Tbk. \\
\end{tabular} & $-0,199$ & 0,842 & Random \\
\hline 36 & WSKT & Waskita Karya Tbk. & $-0,812$ & 0,417 & Random \\
\hline
\end{tabular}

Uji run dilakukan dengan

membandingkan besar asymp sig dua sisi dengan nilai a ( $a=5 \%$ atau 0.05). Jika nilai asymp sig lebih besar a maka harga saham bersifat acak (random).

Jika dilihat dari hasil run test pada tabel di atas terdapat 3 (tiga) saham $(8.3 \%)$ yang pergerakannya tidak bersifat acak atau random, yaitu Bank Central Asia Tbk. $(0.042<0.05)$, Bank Mandiri (Persero) Tbk. $(0.002<0.05)$ dan Gudang Garam Tbk. (0.004< 0.05). Namun sisanya sebanyak 33 saham $(91.7 \%)$ bersifat acak atau random. Hasil ini menunjukkan bahwa pasar modal konvensional efisien dalam bentuk lemah pada periode penelitian yaitu periode 2014-2015.
Hasil secara keseluruhan (ratarata) pada tabel diatas bahwa nilai asymp sig $(0.429>0.05)$. Dengan kata lain H0 diterima sehingga hal ini menunjukkan bahwa perubahan harga pada periode penelitian yaitu periode 2014-2015 bersifat random atau acak. Hal ini menunjukkan bahwa pasar modal konvensional sudah efisien dalam bentuk lemah.

\section{Pembahasan}

Bentuk efisiensi pasar secara lemah ini berkaitan dengan teori langkah acak (random walk theory) yang menyatakan bahwa data masa lalu tidak berhubungan dengan nilai sekarang. Jika pasar efisien dalam bentuk lemah, maka nilai-nilai masa lalu tidak dapat digunakan untuk memprediksi harga sekarang.

Dari hasil pengujian menggunakan run test maka dapat dilihat bahwa terdapat 3 (tiga) saham $(8.3 \%)$ yang pergerakannya tidak bersifat acak atau random, yaitu Bank Central Asia Tbk. $(0.042<0.05)$, Bank Mandiri (Persero) Tbk. $(0.002<0.05)$ dan Gudang Garam Tbk. $(0.004<0.05)$. Namun sisanya sebanyak 33 saham $(91.7 \%)$ bersifat acak atau random. Hasil ini menunjukkan bahwa pasar modal konvensional efisien dalam bentuk lemah pada periode penelitian yaitu periode 2014-2015.

Hasil penelitian ini senada dengan penelitian yang dilakukan oleh Didik (2005) dengan hasil penelitian menunjukkan bahwa IHSG harian, mingguan, bulanan dan tahunan sudah mengikuti pola random walk atau dikatakan sudah efisien. Khajar (2012) dengan menganalisis efisiensi pasar modal syariah dan konvensional bentuk lemah Bursa Efek Indonesia periode 2010. Dengan menggunakan run test, dapat disimpulkan bahwa pasar modal syariah dan konvesional pada periode 2010 sudah efisien paling tidak dalam bentuk lemah. Namun, pasar modal syariah 
lebih efisien dibandingkan pasar modal konvensional. Demikian juga Khajar (2008) dengan melakukan pengujian efisiensi dan peningkatan efisiensi bentuk lemah pada bursa efek Indonesia pada saat dan sesudah krisis moneter pada saham LQ-45 dengan menggunakan 10 saham serta menggunakan uji statistik run test dan autokorelasi dengan hasil penelitian bahwa Bursa Efek Indonesia sudah efisien paling tidak dalam bentuk lemah, namun tidak terjadi peningkatan efisiensi pada periode paska krisis moneter.

Untuk menguji efisiensi bentuk lemah, perubahan harga di masa mendatang seharusnya tidak berhubungan dengan perubahan harga sekuritas di masa lalu. Atau suatu pasar dikatakan efisien bentuk lemah jika harga sekarang sudah mencerminkan seluruh data masa lalu. Karenanya dalam bentuk lemah, data masa lalu tidak dapat digunakan untuk memprediksi harga di masa mendatang.

\section{KESIMPULAN DAN SARAN}

\section{Kesimpulan}

Berdasarkan hasil penelitian terhadap efisiensi pasar modal konvensional bentuk lemah pada sahamsaham yang tergabung pada indeks LQ45 Bursa Efek Indonesia periode 20142015, maka dapat disimpulkan bahwa pasar modal konvensional dapat dikatakan sudah efisien dalam bentuk lemah dengan menggunakan informasi harga saham pada periode 2014-2015. Hal ini dapat dibuktikan dengan melakukan uji runterhadap return mingguan tiap sampel, dimana hasil Asimp sig. dua sisi setiap sampel lebih besar dari nilai alpha (a). Hasil penelitian pada periode 2014-2015 terdapat 33 saham $(91,7 \%)$ bergerak secara acak (random) dan 3 saham $(8,3 \%)$ bergerak secara tidak acak (tidak random).

\section{Saran}

1. Bagi investor dan calon investor

Penelitian ini diharapkan dapat bermanfaat sebagai salah satu media informasi serta sebagai bahan pertimbangan dalam pengambilan keputusan untuk berinvestasi di Bursa Efek Indonesia. Serta dalam berinvestasi di pasar modal agar investor tidak mendapat kerugian, diharapakan selalu memperhatikan informasi yang relevan dalam keputusan beli atau jual saham. Dan tidak menjadikan informasi masa lalu sebagai bahan acuan yang tentunya sudah tidak relevan.

2. Bagi penelitian selanjutnya

a. Pengujian pasar modal pada penelitian ini hanya menggunakan 2 tahun periode pengamatan. Diharapkan untuk penelitian yang akan datang utntuk memperpanjang periode pengamatan yang akan dilakukan. Karena perkembangan pasar modal di Indonesia yang sangat cepat, untuk itu 2 tahun dirasa kurang untuk mencakupi pengujian efisiensi pasar modal bentuk lemah dimasa yang akan datang.

b. Diharapkan untuk penelitian selanjutnya dapat melakukan penelitian dengan jumlah sampel yang lebih besar, sehingga dapat mewakili pasar secara keseluruhan. Mengingat bahwa jumlah saham perusahaan yang semakin meningkat setiap tahunnya.

c. Dalam penelitian ini hanya menggunakan harga saham mingguan, disarankan agar data dapat dipersempit dengan meggunakan data harga saham harian, sehingga diharapkan akan dapat lebih peka terhadap perubahan harga saham.

d. Terdapat beberapa alat analisis untuk menguji efisiensi pasar modal bentuk lemah, namun penelitian ini 
hanya menggukan alat analisis run test. Diharapkan untuk peneliti yang berminat melakuan penelitian sejenis untuk dapat menggunakan korelasi dan regresi linier maupun pengujian cyclical.

\section{DAFTAR PUSTAKA}

Astuti, Novita Santi. (2008). "Analisa Efisiensi Pasar Modal Bentuk Lemah Pada Bursa Efek Jakarta". Tesis. Semarang: Universitas Diponegoro.

Darmadji, Tjipto dan Hendry, M Fakhruddin. (2001). Pasar Modal di Indonesia. Jakarta: Salemba Empat.

Dewi, Retno Kumala. (2008). "Pengujian Efisiensi Pasar Modal Melalui Evaluasi Pergerakan Indeks LQ-45 Di Bursa Efek Indonesia (BEI)". Skripsi. Jakarta: Universitas Islam Negeri Syarif Hidayatullah.

Didik W, Dionysius S. (2005). "Analisis Tingkat Efisiensi Pasar Modal Dalam Bentuk Lemah (Studi Komparasi Pada PT. BURSA EFEK JAKARTA Periode 2000-2004)". Tesis. Semarang: Universitas Diponegoro.

Gumanti, Tatang Ari dan Utami, Elok

Sri. (2002). "Bentuk Pasar Efisien Dan Pengujiannya”. Jurnal Akuntansi dan Keuangan, Vol 4, No.1, Mei 2002, Hal 54-68.

Hartono, Jogiyanto. (2014). Teori

Pertofolio dan Analisis Investasi. Yogyakarta: BPFE-Yogyakarta.

Huda, Nurul dan Edwin Nasution, Mustafa. (2007). Investasi pada Pasar Modal Syariah. Jakarta: Kencana.
Khajar, Ibnu. (2008). "Pengujian Efisiensi dan Peningkatan Efisiensi Bentuk Lemah Bursa Efek Indonesia Pada Saat dan Sesudah Krisis Moneter pada SahamSaham LQ-45". National Confrence on Management Research.

Khajar, Ibnu dan Ristanti. (2012). "Analisis Efisiensi Pasar Modal Syariah dan Konvensional Bentuk Lemah Bursa Efek indonesia Periode 2010". Jurnal Ekobis, Vol.13, No.1 Januari 2012, hal. 89104.

Mar'ati, Fudji Sri. (2012). “Analisis Efisiensi Pasar Modal Indonesia". Jurnal Ilmu Manajemen dan Akuntansi Terapan, Vol.3, No.3 November 2012.

Nasruldin. (2011). "Pengujian Hipotesis Pasar Efisien Bentuk Lemah Pasar Modal di Indonesia". Skripsi. Jakarta: Universitas Islam Negeri Syarif Hidayatullah.

Samsul, Muhammad. (2006). Pasar Modal dan Manajemen Portofolio. Jakarta: Penerbit Erlangga.

Sugiyono. (2010). Metode Penelitian Bisnis. Bandung: Alfabeta.

Suharyadi dan Purwanto, S.K. (2004). Statistika untuk Ekonomi dan Keuangan Modern. Jakarta: Penerbit Salemba Empat.

Tandelilin, Eduardus. (2010). Portofolio dan Investasi Teori dan Aplikasi. Yogyakarta: Penerbit Kanisius.

Yusgiantoro, Purnomo. (2004). Manajemen Keuangan Internasional: Teori dan Praktik. Jakarta: Penerbit Fakultas Ekonomi Universitas Indonesia. 